\title{
Microbiology and atmospheric processes: biological, physical and chemical characterization of aerosol particles
}

\author{
D. G. Georgakopoulos ${ }^{1}$, V. Després ${ }^{2,3}$, J. Fröhlich-Nowoisky ${ }^{2,3}$, R. Psenner ${ }^{4}$, P. A. Ariya ${ }^{5}$, M. Pósfai ${ }^{6}$, H. E. Ahern ${ }^{7}$, \\ B. F. Moffett ${ }^{7}$, and T. C. J. Hill ${ }^{7}$ \\ ${ }^{1}$ Agricultural University of Athens, Athens, Greece \\ ${ }^{2}$ Max Planck Institute for Chemistry, Mainz, Germany \\ ${ }^{3}$ Johannes Gutenberg University, Mainz, Germany \\ ${ }^{4}$ University of Innsbruck, Innsbruck, Austria \\ ${ }^{5}$ McGill University, W. Montreal, Canada \\ ${ }^{6}$ University of Pannonia, Veszprem, Hungary \\ ${ }^{7}$ University of East London, London, UK
}

Received: 31 January 2008 - Published in Biogeosciences Discuss.: 8 April 2008

Revised: 3 April 2009 - Accepted: 24 April 2009 - Published: 30 April 2009

\begin{abstract}
The interest in bioaerosols has traditionally been linked to health hazards for humans, animals and plants. However, several components of bioaerosols exhibit physical properties of great significance for cloud processes, such as ice nucleation and cloud condensation. To gain a better understanding of their influence on climate, it is therefore important to determine the composition, concentration, seasonal fluctuation, regional diversity and evolution of bioaerosols. In this paper, we will review briefly the existing techniques for detection, quantification, physical and chemical analysis of biological particles, attempting to bridge physical, chemical and biological methods for analysis of biological particles and integrate them with aerosol sampling techniques. We will also explore some emerging spectroscopy techniques for bulk and single-particle analysis that have potential for in-situ physical and chemical analysis. Lastly, we will outline open questions and further desired capabilities (e.g., in-situ, sensitive, both broad and selective, on-line, time-resolved, rapid, versatile, cost-effective techniques) required prior to comprehensive understanding of chemical and physical characterization of bioaerosols.
\end{abstract}

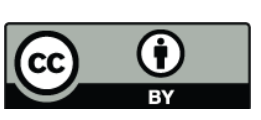

Correspondence to:

D. G. Georgakopoulos

(dgeorga@ aua.gr)

\section{Introduction}

Aerosols are a suspension of liquid, solid, or multiple-phases of condensed matter in the atmosphere with size ranges of ca., 0.001 to $100 \mu \mathrm{m}$. From the size-distribution, aerosols are divided into three categories: (1) nuclei mode $(0.005$ to $0.1 \mu \mathrm{m})$, accumulation mode $(0.1-2 \mu \mathrm{m})$ and coarse mode $(>2 \mu \mathrm{m})$ (Walter, 2001). The particle size is determined by the formation processes and subsequent atmospheric chemical and physical transformations. Bioaerosols are a fraction of organic aerosols and are generally defined as living (e.g., bacteria, fungi, viruses), dead, debris, or by-products of biological activities such as semi-volatile organic compounds and micromolecules. As bioaerosol definition demonstrates, this group of aerosols includes a wide range of organic matter with large degree of variability in physical and chemical characteristics such as size, shape, phase, composition, structure, solubility, volatility, hygroscopicity and surface properties. Bioaerosols can be single spore, pollen, bacteria and viruses, to biological aggregates, to products and by-products as well as attached to non-biological particles.

Bioaerosols may have a significant impact on climate, acting as cloud condensation nuclei and ice nuclei which can initiate precipitation. Aerosol particles of biological origin (cells, cell fractions or organic matter of animal, plant and microbial origin) form a significant portion of atmospheric aerosols, sometimes reaching close to $50 \%$ numerically of all

Published by Copernicus Publications on behalf of the European Geosciences Union. 
aerosol particles (Jaenicke, 2005). Research on bioaerosols has mostly focused on their detection and enumeration related to public health hazards, and several methods for sampling, and measurement of aerosol number density, shape, optical, and surface properties, chemical characterization of condensed and semi-volatile matter and identification of biological particles have been developed. There is not one technique, however, capable to fully capture the physical and chemical complexity of biological matter.

Methods of characterization target either the entire cell or specific cell components in a sample of air or precipitation. Methods that target the entire cell involve microscopic examination, immunological identification, or, in the case of microorganisms, culture on various nutrient media. Methods to detect cell components are very diverse: they target biochemical markers (proteins, fatty acids, sugars) or nucleic acids (DNA and RNA) and are often a combination of different strategies.

Biological ice nuclei (bacteria, pollen, plankton, lichens) are active at relatively warm temperatures, between -2 and $-9^{\circ} \mathrm{C}$, a range where very few, if any, inorganic ice nuclei are active . Although the ice nucleation property of various organisms has been documented (reviewed by Lundheim, 2002), detailed studies on the mechanism have been done only for bacteria. Several bacterial ice nucleation genes have been cloned from all known species with ice nucleation activity. The genes have been sequenced and the gene product, a protein on the outer cell membrane, has been isolated and its structure described (Warren, 1995). For other ice nucleating organisms, the nature of the ice nucleation factor is not known. Even if the gene responsible for this property is present in the genome, bacterial ice nucleation is not always fully expressed. Nutritional and environmental factors influence this expression and the subsequent ice nucleation activity of the bacterium (O'Brien et al., 1988; Nemecek-Marshall et al., 1993). It is not known if such variability exists in other organisms with ice nucleation activity. It is possible to characterize all species present in an aerosol sample and identify those with reported ice nucleation activity. It is a lot more difficult, however, to directly prove that these species are ice nucleation active in situ.

Here we present the main methods that are used to characterize the biological component of aerosols, starting with methods to quantify and identify entire cells, followed by methods to measure total biomass or specific cell components and those that allow quantification and identification of cells down to species level. We review the techniques for studying specific properties of individual biological particles. We also show that it is possible to identify and quantify a class of biological ice nuclei in bioaerosols, ice nucleation active bacteria, the best described biological ice nuclei.

This paper originates from the European Science Foundation workshop on Microbial Meteorology held in Avignon, France in 2006. It is part of a series of papers from this workshop in this journal.

\section{Methods based on detection of entire cells, spores, pollen and viruses}

\subsection{Cell culture}

Classic isolation techniques on nutrient media have been widely used to enumerate and characterize airborne bacteria and fungi (Lighthart, 1997; Andreeva et al., 2001; Bauer et al., 2002). These are collected by impaction on a filter or an agar surface and, after incubation, visible colonies that develop are enumerated and subsequently identified. Bacteria are identified biochemically (Gram stain, metabolic profile of carbon sources, enzymes produced, pathogenicity, etc). Fungi are identified mainly by morphological characteristics of spores and fruiting bodies. An advantage of this method is the compatibility with several types of air samplers, designed to be fitted with Petri dishes or filter holders. A limitation is that it underestimates the actual number and diversity of microorganisms in a bioaerosol, because only microorganisms that are metabolically active and reproduce under the imposed culture conditions will be enumerated, but not those in the viable but non-culturable state. In filtered air collected over Salt Lake City, Radosevich et al. (2002) found that only $0.08 \%$ of all bacteria were cultivable, while in cloud water samples collected at the Puy de Dôme, France, by Amato et al. (2005) the range was $0.02-0.8 \%$. Interestingly, Tong and Lighthart (2000) recorded a high variability in summer above pastures of $0-50 \%$, but typically $<10 \%$. As, there is no nutrient medium suitable for growth of all microorganisms, a variety of media and incubation conditions is necessary for a provisional assessment of bioaerosol diversity or enumeration of a selected group of microorganisms. For bacteria, R2A, designed for stressed, water-borne heterotrophs, was recommended as a standard general medium by Kellogg and Griffin (2006), and when used with Trypticase Soy by Amato et al. (2007) did recover a wide diversity of Grampositive and -negative species. However, to revive bacteria from a $3.6 \mathrm{~km}$ deep ice core sample, Christner et al. (2001) used 10 media. Even with groups considered amenable, culturing may show bias. For example, when Pseudomonads isolated from a cloud sample on nutrient agar amended with cycloheximide were compared with Pseudomonads identified in the same sample by direct DNA-based analysis using ARDRA (see below) the two sets tended to cluster into separate groups (Fig. 1).

Fungi are selectively isolated in acidified media and media containing antibiotics to prevent bacterial growth. To eliminate variability in results, especially for microorganisms found in low numbers in bioaerosols, large sample sizes and replications are required. A source of variability is also the error associated with air samplers where air passes through holes: microorganisms that pass through the same hole and land on the agar surface as aggregates may produce only one colony, thus underestimating their actual number (manufacturers do provide statistical corrections for the number of 


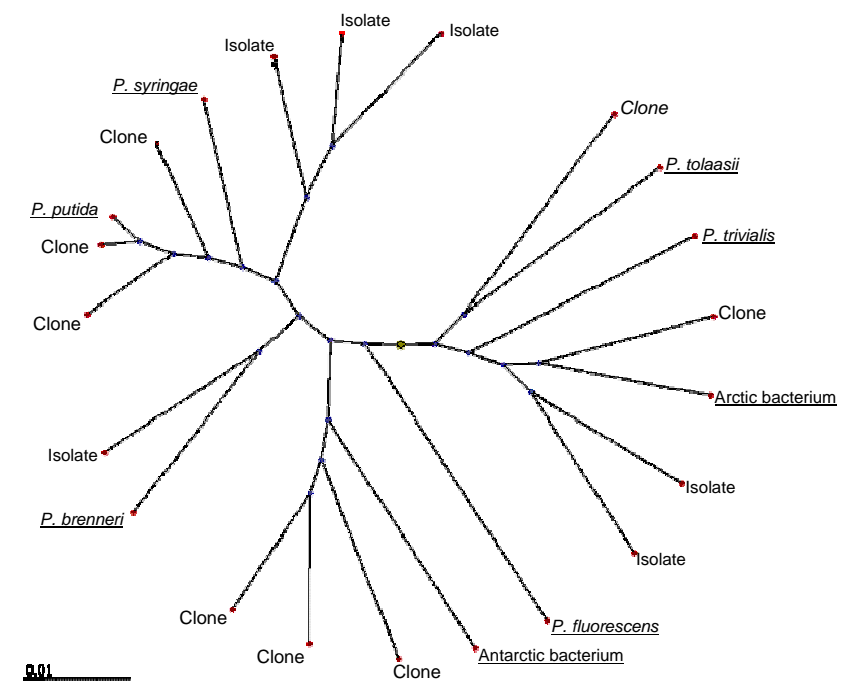

Fig. 1. Comparison of strains obtained by culturing (labelled "Isolate") with those obtained by direct DNA-based analysis (labelled "Clone") of a Scottish cloud sample. Reference strains are shown underlined, and the scale bar equates to a $1 \%$ difference between sequences (region used was from 530 to 1390 of the 16S rRNA gene).

microorganisms). In principal, however, we have to acknowledge that cultivation means selection, and the number of culturable microorganisms in environmental samples is generally low (1\% or less). Generally, unless one is interested in a particular group whose growth requirements are well documented, culturing is not a practical approach for community characterisation.

\subsection{Microscopy}

Microscopic examination and enumeration of airborne biological particles is done with air samples that are drawn onto appropriate glass slides, glass rods, or filters fitted on the sampler. Slides are divided into grids and many (typically $\geq 30$ ) fields of view are necessary to estimate the number of particles of biological origin in a given volume of air. For most microorganisms, species identification is not possible without processing the sample with a technique designed to identify taxa or species, such as immunospecific staining with fluorescent dyes. To facilitate enumeration of fungal spores, for example, several stains that differentiate fungal spores from debris are available (Burge, 1995). Fungal spores and pollen are also identified by morphology, although it requires a significant level of expertise. Bacteria are normally counted after staining with a fluorescent dye, such as DAPI (4'6 diamidino-2-phenylindol) or SYBR Green I and II, that binds to DNA; however, a large number of bacteria must be present in the sample (over $10^{4} 1^{-1}$ ) to avoid errors. The number of bacteria in cloud water can be much lower $\left(10^{3} 1^{-1}\right)$, thus special care is necessary to prevent overestimation of cell densities (Sattler et al., 2001). Bac- teria can also be drawn into a liquid which is subsequently concentrated for improved counting. An advantage of microscopy over culture techniques, especially when dyes such as acridine orange are used to detect viable cells, is the possibility to enumerate the non-culturable fraction of microorganisms, which may be significant. However, it is possible to misidentify microorganisms from debris of non-biological origin. The use of fluorescent in situ hybridisation (FISH) with specific probes targeted at the small subunit of ribosomal RNA (16S rRNA) (Amann and Ludwig, 2000) is now a widely used tool to distinguish certain groups of bacteria or even clones (Pernthaler et al., 1998). For the creation of probes, see Sect. 3.3.2. The method also works in dilute samples but seems to be limited by the number of ribosomes per cell. To overcome these problems, Pernthaler et al. (2002) developed a method (CARD-FISH) that enhances the fluorescent signal by more than an order of magnitude. This method allows, in principle, counting of the number of cells by using a general probe for Bacteria or Archaea, but detection of specific groups, genera or species is time consuming and limited by their total abundance.

It is more difficult to determine the total number of viruses in environmental samples. The presence of viruses in bioaerosols is usually monitored for human, animal, or plant health purposes, but in most cases, only one or few species of viruses are counted, using methods to specifically detect particles of the viruses under investigation. Studies of total virus particle numbers in environmental samples are rare and rely mostly on counts of virus-like particles in several fields of microscopic observation after staining with fluorescent dyes (Noble and Furhman, 1998).

\subsection{Immunological detection}

Immunological detection has been widely used to detect microorganisms of medical or phytopathological significance. Antibodies isolated from the serum of inoculated animals can detect a number of different microorganisms. They are produced by the immune system of the animal as a reaction to specific antigens on the surface of the microorganism, such as proteins, polysaccharides, etc. It is therefore necessary to produce antibodies with specificity towards a single species, to avoid false positive detection and errors in counts. Monoclonal antibodies offer increased specificity and may be useful for characterization of bioaerosols.

Antibodies can be used as vectors carrying a label to visualise a cell or virus. Labels include fluorescent dyes (fluorescence microscopy), enzymes (enzyme immunoassay) or a radioactive compound. In fluorescence microscopy, only cells to which the antibody/fluorescent dye conjugate binds will be visible (fluoresce) under the microscope. Theoretically it should be possible to selectively stain and detect ice nucleation active bacteria, using an antibody with specificity for the ice nucleation protein. Although antisera against this protein have been produced they have not been used to detect 
bacterial ice nuclei in environmental samples. These methods have been used to measure allergens in bioaerosols, and are compatible with bioaerosol sampling techniques (Chapman, 1995).

\subsection{Flow cytometry}

In flow cytometry, a suspension of cells (from culture or environmental samples) is passed rapidly in front of a measuring window. Light emitted from a source is scattered by particles in the liquid and several parameters such as size, shape, biological and chemical properties can be measured simultaneously. Autofluorescence or indirect fluorescence of cells after labelling is also used to detect cells. Cell labelling is done with DNA or RNA-binding fluorescent dyes (as described in section 2.2), fluorochromes conjugated to taxa-, species- or protein-specific antibodies, or probes for nucleic acids. It is possible to differentiate live from dead cells, metabolically active from non-active cells, particles of biological and nonbiological origin, and to identify taxa, or even species, and viruses. For bioaerosol samples drawn into a liquid, a minimum concentration of 1000 cells ml$^{-1}$ is necessary for detection. This limitation can be overcome by allowing for longer sampling times. Viruses in environmental samples can also be identified using SYBR Green I (which binds to their nucleic acid) and counting for particles with scatter characteristics of known viruses (Marie et al., 1999). Flow cytometry offers great speed in sample processing and identification. Automation allows for more accurate enumeration of biological particles in bioaerosols and flow cytometry has been used to monitor biocontaminants in indoor aerosols (Birenzvige et al., 2003; Stetzenbach et al., 2004; Chi and Li, 2005).

To identify bacterial ice nuclei in bioaerosols using flow cytometry, a specific antibody recognizing the ice nucleation protein on cell membranes, or a nucleic acid probe specific for the IN gene conjugated to a fluorochrome, could be used.

\subsection{Physical and chemical characterization of biological atmospheric particles: single particle methods}

The physical and chemical characterization of atmospheric particles traditionally involves the study of bulk samples. However, since biological particles form a small fraction of the total aerosol, the analysis of bulk samples rarely produces detailed information on the properties of such particles. In contrast, studies of individual particles can provide data on the sizes, shapes, compositions, structures, and surface properties of any types of particles. Various microscope and spectroscopic methods are now routinely applied in atmospheric science, but single-particle studies specifically aimed at understanding the atmospheric effects of biological particles are scarce. Below we review the techniques, both established and emerging, that have been used or are potentially useful for studying specific properties of individual biological particles.
In general, the distinct types of biological particles have well-defined size ranges and characteristic shapes that enable their identification using microscope techniques (Table 3). The larger particles, including spores and pollen, can be studied using optical microscopy (OM) and epifluorescent microscopy (described in Sect. 2.2). Scanning electron microscopy (SEM) in combination with energy-dispersive X-ray spectrometry (EDS) has been used for studying single atmospheric particles since the 1980s (Anderson et al., 1988; van Borm et al., 1989). In the past two decades SEMs equipped with field-emission guns became available and their improved spatial resolution made the observation of the morphologies of bacteria and viruses also possible (Ebert et al., 2004). Using secondary electron images, the threedimensional shapes of the particles can be visualized. Chemical information is usually obtained using an EDS detector attached to the microscope. EDS analyses of the concentrations of light elements (including $\mathrm{C}, \mathrm{N}$, and $\mathrm{O}$ ) are generally inaccurate or semi-quantitative at best (Osán et al., 2000; Worobiec et al., 2003); thus, elemental compositions are not generally useful for the identification of specific biological components. Nevertheless, on the basis of size, shape, and elemental composition, the particles can be confidently assigned into relatively broad categories such as "marine", "crustal", or "biological" (Ebert et al., 2004; de Hoog et al., 2005; Laskin et al., 2006). A great advantage of SEM is that particle analysis can be automated and thousands of single particles can be analyzed in each sample.

Transmission electron microscopy (TEM) provides the highest specificity among the microscope methods for the analysis of several particle properties. The sizes and the twodimensional projected shapes of any types of biological particles, including bacteria and viruses, are conveniently studied using TEM (Matthias-Maser and Jaenicke, 1994; Pósfai et al., 2003; Niemi et al., 2006). The high resolution of the TEM permits the observation of minute details within particles. Particle aggregations and thus the degree of internal mixing of the individual components of the aerosol can be assessed. A unique capability of TEM is that the structures of particles can be studied using electron diffraction (ED). Structural information is used for identifying crystalline substances and for obtaining a better understanding of the structure-dependent properties of amorphous particles (Pósfai et al., 1995; Kis et al., 2006).

Elemental compositions can be obtained in the TEM by using EDS or electron energy-loss spectroscopy (EELS). Compared to EDS analysis in the SEM, the TEM provides more spatial detail within individual and potentially complex particles; however, the TEM is operated manually, and much fewer particles can be analyzed than in an automated SEM. EELS is particularly suited for the study of light elements (such as $\mathrm{C}, \mathrm{N}$, and $\mathrm{O}$ ) that are important in biological particles (Katrinak et al., 1992; Chen et al., 2005). By selecting energy windows at specific core-loss regions of the EEL spectrum, it is possible to obtain compositional 
maps that show the distributions of the selected elements within the particles. This technique is usually referred to as energy-filtered TEM (EFTEM), and is gaining popularity in the study of atmospheric particles (Maynard, 1995; Pósfai and Molnár, 2000; Maynard et al., 2004; Pósfai et al., 2004; Chen et al., 2005). A major limitation of EFTEM is that the particles have to be thin $(<100 \mathrm{~nm}$ in the case of organic particles) for a meaningful analysis.

Since TEM micrographs provide only two-dimensional projections of the studied objects, it has been a problem to obtain reliable data about the third dimensions of particles. As demonstrated recently, accurate three-dimensional morphological data can be obtained from atmospheric particles using electron tomography (ET) (van Poppel et al., 2005). ET involves the acquisition of a series of images taken at different specimen tilt angles. If the tilt range is large enough (at least $\sim \pm 70^{\circ}$ ), and images are obtained at $1^{\circ}$ or $2^{\circ}$ intervals, the shape of the particle can be reconstructed from the series of images. Although ET is time-consuming and cannot be performed on a large number of particles, it can provide important data for particles that have complex shapes. Since shapes significantly affect the optical properties of particles, ET will likely emerge as a useful tool in the study of individual atmospheric particles, including those of biological origins.

Since in most studies that are concerned with the atmospheric effects of particles the objective is a general characterization of the aerosol, the specimens are, in general, not prepared in any special way to preserve biological structures. Moreover, in conventional SEM and TEM the sample is in vacuum and thus dehydrates and its morphology may change, potentially making it impossible to recognize the particles. These problems have been partly overcome by recent developments of electron microscopes in which the sample can be studied in low-vacuum conditions. The environmental SEM (ESEM) is now an established tool in the study of atmospheric particles, and has been used for characterizing the hygroscopic behaviour of a variety of particle types and for studying heterogeneous surface reactions (Ebert et al., 2002; Krueger et al., 2003; Kaegi and Holzer, 2003). Environmental TEM (ETEM) is an emerging technique that has only been used in a handful of atmospheric studies but, on account of the superior resolution of TEM, appears to hold great promise for the analysis of biological particles (Wise et al., 2005). Certainly, near-atmospheric conditions in the sample chambers of both the ESEM and the ETEM can only be achieved at the expense of the image resolution of the corresponding high-vacuum instruments. Yet, the use of ESEM and ETEM offers exciting new possibilities for the study of biological atmospheric particles.

Atomic force microscopy (AFM) appeared as a promising complementary technique to the electron microscope methods for studying atmospheric particles (Friedbacher et al., 1995; Pósfai et al., 1998; Barkay et al., 2005). AFM operates under ambient conditions and so the shapes of the particles are not affected by the vacuum as in conventional SEM and TEM studies. In a controlled specimen environment both the hygroscopic and chemical behavior of aerosol particles can be observed (Köllensperger et al., 1999; Ramirez-Aguilar et al., 1999). However, the lack of direct compositional information and artifacts arising from the interactions between the cantilever tip and the specimen has hindered the widespread use of AFM in atmospheric science. Nevertheless, AFM could prove to be the method of choice for solving specific problems related to the surface properties of bioaerosol particles.

All microscope methods are offline: the samples have to be collected on a surface, then stored and studied under various conditions, all of which can potentially change the properties of the original particles. Aerosol mass spectrometry (AMS) is immune from such problems, since AMS provides almost real-time analysis of aerosol particles. Typically, airborne particles enter a vacuum chamber, where single particles are detected and sized by a continuous laser beam, and then ablated and ionized by a laser pulse. The resulting ions are analyzed using a time-of-flight mass spectrometer. Both positive and negative ion mass spectra can be collected. There are several major types of instrumental setups for obtaining mass spectra of individual aerosol particles, the discussion of which is beyond the scope of the present study. Depending on the particular type of instrument, several acronyms are in use, including AMS, PALMS (Particle Analysis by Laser Mass Spectrometry), ATOFMS (Aerosol Time-Of-Flight Mass Spectrometry), and MALDI (MatrixAssisted Laser Desorption/Ionization Mass Spectrometry). Details about the various AMS methods can be found in recent reviews by Sullivan and Prather (2005) and Murphy et al. (2006).

In addition to being an effectively real-time method, the main advantage of AMS is its high sensitivity. Very low concentrations $\left(<0.01 \mu \mathrm{g} \mathrm{m}^{-3}\right)$ of both inorganic and organic constituents can be detected. The AMS is also used for the quantitative chemical analysis of single particles, although the results are affected by ionization efficiencies and matrix effects, which make the reliable analysis of both inorganic components and organic molecular compositions difficult. Nevertheless, by the analysis of fragment ions that are specific to distinct microorganisms, the types of viruses, bacteria, and fungi present in the air can be assessed on an individual-particle basis. The analysis of biomarker ions forms the basis of bioaerosol mass spectrometry (BAMS), a new and highly efficient method for the detection of both spores and vegetative cells of airborne pathogens and bioterrorism agents (Russell et al., 2004, 2005; Tobias et al., 2005; van Wuijckhuijse et al., 2005; Beddows and Telle, 2005). AMS is now a widely used single-particle method in aerosol science, with unique capabilities for obtaining species-specific data from biological particles. However, the detailed chemical composition and structural information can still not be produced using today's AMS protypes. 
Fourier Transform Infrared Spectroscopy (FTIR) and Nuclear Magnetic Resonance (NMR) Spectroscopy (Posfai et al., 1994; Blando et al., 1998; Ariya et al., 2002; Sobanska et al., 2003; Liu et al., 2005; Cote et al., 2008) for biomaterial atmospheric analysis are grouped here together because the information available from both methods, and thus their strengths and drawbacks, are similar. A larger fraction of the material is amenable to analysis than with chromatographic methods (Blando et al., 1998), and the sample need not necessarily be pre-fractionated or extracted, although it may in fact be further fractionated before NMR (Decesari et al., 2000, 2001; Sannigrahi et al., 2006), or rinsed with successive solvents between FTIR spectra (Blando et al., 1998; Maria et al., 2003).

Similarly, FTIR provides functional group information which can be used to compare samples to material of known origin or age. An FTIR study of organic aerosols in the Smoky Mountains (Blando et al., 1998) determined the size distribution of compound classes, including carbonyls and organosulfur compounds, finding that much of the material was polar, and showed that FTIR could characterize amounts of material too small to be analyzed chromatographically. FTIR with successive solvent rinses showed that a variable fraction $(60-90 \%)$ of organic material in size-fractionated aerosols in the Eastern Caribbean free troposphere was hydrophobic; functional groups in each size fraction were quantified. Functional groups may also be summed to estimate total organic carbon (Blando et al., 1998; Zappoli et al., 1999; Maria et al., 2002, 2003; Decesari et al., 2007; Gilardoni et al. 2007; Samburova et al., 2007), avoiding some of the artifacts which affect TOCA.

\subsection{Characterization of biological ice nuclei in environ- mental samples}

Biological ice nuclei in environmental samples such as bioaerosols and precipitation can be detected and enumerated when particles in samples are isolated and suspended in water, because they cause immersion freezing of water (Vali, 1971) at various subzero temperatures. This test, however, cannot differentiate biological ice nuclei from abiotic ones, although all known biological ice nuclei are active at warmer temperatures than abiotic nuclei. A simple and elegant approach has been described in two recent papers by Christner et al. (2008). They estimated the abundance of biological ice nuclei in snow and rain by treating their samples with agents that destroy cell integrity and ice nucleation activity. In all known biological ice nuclei, intact cells are more active than disrupted cells or isolated cell components (Warren, 1995). Christner et al. treated their samples with heat $\left(95^{\circ} \mathrm{C}\right)$ to denature most proteins, and lysozyme, an enzyme that destroys the cell wall of bacteria. By estimating the number of total ice nuclei and eliminating the activity of biological ice nuclei in a sample, they calculated their percentage in samples of snow and rain. This strategy can easily be adapted to detect biological ice nuclei in samples of bioaerosols, for example, when isolated bioaerosol particles are finally suspended in water.

\section{Methods based on detection of cell components}

\subsection{General biomass measures}

These are useful to determine the organic carbon content of aerosols, but the small biomass of cloud/rain samples limits the available methods. C:N:P ratios typical of organisms are often compared to marine plankton samples from where the classical Redfied stoichiometry of 106:16:1 has been derived. However, as the group of Mikal Heldal from the University of Bergen, Norway, has shown for marine and freshwater bacteria, this ratio fluctuates over a wide range and may thus not be used as an unambiguous indicator of living cells.

\subsection{Measures of ATP levels}

Irrespective of the substrate metabolised the ultimate energy carrier for biosynthesis in all cells is ATP (adenosine triphosphate). Energy cannot be stored in ATP as it is transient and only produced when cells are active. For many years it has been used by soil scientists and food microbiologists as a measure of microbial viability. Amato et al. (2007) were the first to measure ATP levels in cloud water and, based on the available figures for the amount of ATP per viable cell, concluded that the vast majority of bacteria in their eight samples were in a viable but non-culturable state.

\subsection{Methods based on detection and analysis of nucleic acids}

\subsubsection{DNA/RNA isolation}

One major limitation of DNA extraction is that all potential sources (e.g., bacterial cells, fungal spores, or plant tissues) all require different extraction conditions. DNA is extracted either from liquid samples or filters. To settle particles in liquid samples a centrifugation force of $3000 \times g$, for at least $20 \mathrm{~min}$, seems to be the minimum recommended, but $\geq 5000 \times g$ is preferable. If cloud water, rain or snow is collected directly into RNAlater (essentially a saturated solution of ammonium sulphate made by Ambion), to also preserve the RNA, it should be diluted to a final sample:RNAlater volume ratio of 1:1 immediately before centrifugation otherwise it may be too dense to allow the particles to settle (its density also requires that it be continuously stirred during collection). Since the pellet is often invisible and easily disturbed, we recommend removal of the supernatant by aspiration. Filters can either be cut up and used directly for DNA extraction (so long as the filter used doesn't bind DNA) or shaken to dislodge the aerosol particles. Peccia and Hernan$\mathrm{dez}$ (2006) recommend shaking filters at $100 \mathrm{rpm}$ for $12 \mathrm{~h}$ in 
conical flasks on a rotary shaker. However, we found that this may be too gentle and that additional intermittent vigorous shaking by hand was required.

For DNA extraction, various methods and kits are available, and the method used should be chosen depending on the aims of the analysis (Després et al., 2007). In comparison to other commercial kits the FastDNA Spin kit for soil (Bio 101 Systems) used with Lysing Matrix E proved to be the most appropriate to extract DNA from different organisms (Bacteria, fungi, plants, animals, Archaea) on different filter materials (glass or quartz fibre, cellulose nitrate, polypropylene). Lowering the $\mathrm{pH}$ of the extractant to $\leq 7.5$ with $3 \mathrm{M}$ sodium acetate ( $\mathrm{pH} 5)$ before the silica step will dramatically increase DNA recovery in dilute samples. Kits tend to use chaotropic guanidine salts for lysis and are reliable and very convenient. However, we got higher DNA yields from bacteria and no carry-over of PCR-inhibiting salts using the surfactants SDS and CTAB (Ahern et al., 2007). Pre-digestion of the sample with both lysozyme (to digest cell walls, especially of Gram positives) and proteinase K (Read, 2001) is important, as is the use of bead beating to mechanically disrupt cells.

The subsequent PCR reaction can be inhibited by additional substances present in the samples, which bind to the template DNA or to the polymerase. This inhibition can be severe and prevent DNA amplification completely. The characteristics of such inhibitory substances are only partly understood. It is for example known that humic acids act as inhibitory substances, and also that soot or sea salt particles might influence the reaction. Preliminary observations reveal some patterns: the more air sampled and the finer the particles filtered $\left(\mathrm{PM}_{2.5}\right.$ vs. $\left.\mathrm{PM}>2.5\right)$ the more inhibition; aerosols from highly industrialised cities show more inhibition than from smaller cities in rural regions; and we have found that samples from the coast can be very inhibited by the salt.

To reduce inhibition it is necessary to remove or minimize these inhibitors by performing additional purification steps or by reducing the amount of template DNA (and its coextracted inhibitors)(see Peccia and Hernandez 2006). However, we have found that reducing the quantity of DNA or increasing the amount of polymerase enzyme were often not successful (but worth testing). We do, however, recommend using kits for extracting DNA from soils because they are designed to cope with common inhibitors such as humic acids. In a careful comparison of methods, Kemp et al. (2006) recommended repeated silica extractions, using Promega Wizard ${ }^{\circledR}$ PCR Preps, to simply remove inhibitors. We have also found that running the genomic DNA though a $0.5 \%$ agarose gel is highly effective at removing inhibitory salts and tannins; the tannins run ahead of the DNA enabling the high molecular weight DNA $(>10 \mathrm{~kb})$ to be cut out and the gel used directly for PCR. Choice of Taq also matters; using the same extract some gave no product while others amplified well. In conclusion we found that there is no general strategy to overcome inhibition. For each reaction one needs to experiment empirically with the conditions, but especially with the extraction kit and the choice of polymerase.

The high sensitivity of PCR introduces the risk of amplifying any trace amounts of contaminant DNA which, if undetected, may cause serious misinterpretation of the data. For example, Després et al. (2007) found that while glass fibre filters were sterile, up to $1 \mu \mathrm{g}$ DNA was found on new polypropylene filters. However, contamination with DNA or even bacterial or fungal spores can be avoided by decontamination prior to sampling. For example, filters can be autoclaved (and/or pre-soaked in $3 \% \mathrm{H}_{2} \mathrm{O}_{2}$ for $2 \mathrm{~h}$ ) or baked at $300^{\circ} \mathrm{C}$ for $12 \mathrm{~h}$. Peccia and Hernandez (2006) warn against relying upon autoclaving alone for decontamination. Gas plasma $\mathrm{H}_{2} \mathrm{O}_{2}$ sterilisation can be used on larger equipment. Additionally, gloves and breamed tweezers should be used to avoid direct contact. In any case, it is necessary to extract blanks along with the samples to monitor for possible contamination, and if detected, such contamination can be analyzed and compensated for (Després et al., 2007).

Techniques can be used to discriminate between DNA from sources that are alive or active, although the distinction between these is debatable. RNA rather than DNA can be isolated as this gives an indication of which cells are active. Alternatively a vital stain can be used and the viable cells obtained by flow cytometry. A simpler approach, EMA PCR, based on the same concept of membrane integrity but using ethidium monoazide, can be used to prevent DNA from dead cells being included in the analysis (Knut et al., 2004). However, this technique has proven to be efficient only for a limited number of species. A more robust technique with wider applications is based on propidium monoazide (PMA) for selective removal of DNA from dead cells in a sample (Nocker et al., 2006).

\subsubsection{Using the Polymerase Chain Reaction (PCR) with bioaerosols}

The PCR has revolutionised microbial ecology by facilitating the direct analysis of nucleic acids in any sample. It is used to copy, many million-fold, specific regions (typically $<1000$ bases) of the genome, providing enough for analyses. Often $<100$ target molecules are sufficient template for a successful amplification, and a single bacterium or fungal spore can be detected in fully optimised reactions (e.g., Zeng et al., 2004).

The most common gene used for community analysis is the gene coding for the 16S rRNA subunit of the ribosomes (coded by16S rDNA) of Bacteria and Archaea, and its analogue, the gene for the 18S rRNA subunit of the ribosomes (coded by $18 \mathrm{~S}$ rDNA), in eukaryotic microorganisms, animals and plants. It is an essential structural component of the ribosome, a cell organelle which synthesises protein. Parts of its sequence are the same in all bacteria while others vary to differing degrees. This allows the 
conserved sequences to be targeted for attachment of the two flanking primers that are required for PCR amplification, while intervening variable regions are used for analysis of diversity and identification. Universal $16 \mathrm{~S}$ rDNA and $18 \mathrm{~S}$ rDNA primers are given in Després et al. (2007) and Ahern et al. (2007), and probeBase (http://www.microbial-ecology. net/probebase/) and probeCheck (http://131.130.66.200/ cgi-bin/probecheck/content.pl?id=home) provide comprehensive databases of rDNA primers and probes for prokaryotes and eukaryotes.

Often the PCR products are sequenced and then the next task is to determine the identity of the DNA. This is achieved by comparing the new sequence to those already available by interrogating online databases. For 16S rRNA we recommend the Ribosomal Database Project (http://rdp. cme.msu.edu/), containing over 400,000 sequences. The ARB database (http://www.arb-home.de/) contains many additional sequences but requires UNIX to run. For bacteria the generally accepted levels of discrimination are $99 \%$ similarity for strains, $97-99 \%$ for species and $95-97 \%$ for genera. Often a complete or very close match is obtained. Increasingly the closest matches are environmental clones which give little useful information other than where the sample originated. For broader coverage to include other sources of DNA, the EMBL Nucleotide Sequence Database or one of its partners is recommended. This database is produced in collaboration with GenBank (USA) and the DNA Database of Japan (DDBJ). Each collects a portion of the total sequence data reported and all sites are updated daily. The BLAST search engine provided by the National Center for Biotechnology Information (http://www.ncbi.nlm.nih.gov/BLAST/) is the easiest to search for closest matches.

A recent approach to characterize bioaerosols used bacterial 16S rRNA genes in microarrays (Brodie et al., 2007). Microarrays are chips carrying sets of DNA from known genes in a predetermined order on the surface. The gene pool can be designed to represent a small or large group of organisms. DNA from environmental samples is labelled, heated and allowed to hybridize with the DNA on the microarray. If complementary sequences exist in both the sample and the microarray, then they hybridize and the sequence determined from the position of the fluorescence on the chip. Brodie et al. (2007) constructed a microarray carrying $16 \mathrm{~S}$ rRNA genes (using 16S rDNA) from most known bacterial taxa and used it to analyse the diversity and changes of the bacterial microflora in urban aerosol samples. Their method required several steps of normalization and appropriate statistical analysis, and was more sensitive in detecting bacterial taxa than the standard method of cloning and sequencing amplified 16S rDNA fragments.

To obtain greater resolution, other genes, or the regions between genes, can be used. For speciating fungi the spacer region between rRNA genes is used while for plants the $r b c \mathrm{~L}$ chloroplast gene provides additional taxonomic information (see Després et al., 2007). To increase intrageneric discrim- ination within the Pseudomonads, Yamamoto et al. (2000) recommend the combined use of the $g y r \mathrm{~B}$ and $r p o \mathrm{D}$ genes.

There are no universal primers available to analyse virus particles in the same way, and considering their numbers and diversity, this is a serious impediment. Viruses in bioaerosols can be detected by using specific primers for each species in the PCR reaction, but quantification of the total content of viruses in a sample of bioaerosols cannot be done with PCR. Moreover, for RNA viruses, reverse transcription of the viral genome from RNA to DNA precedes PCR detection.

Most known alleles of the ice nucleation gene have been successfully amplified using PCR on mostly limited sets of isolates (see Table 1). Primers for inaW (P. fluorescens) have had only limited success, due to its variability; Ahern (2007) found three times greater sequence difference (in block 4 of the core and the $\mathrm{C}$-terminal region) between two ina $\mathrm{W}$ genes (Warren at al. 1986 and isolate 26 in Castrillo et al. 2000) than exists between inaZ, $\mathrm{K}$ and V.She recommended obtaining entire gene sequences, using shotgun cloning, from a range of isolates to assess its true diversity. Primers with broader range are being designed (Guilbaud et al. 2007). These target the ina $\mathrm{W}$, ina $\mathrm{Y}$ and ina $\mathrm{Z}$, ina $\mathrm{K}$ and ina $\mathrm{V}$ alleles and have been tested on many diverse ice nucleation active strains of $P$. syringae, $P$. viridiflava, $P$. fluorescens, $P$. putida, Panteoa agglomerans and Xanthomonas campestris.

If RNA (e.g., 16S rRNA or the messenger RNA of an actively transcribed IN gene) is the target, the initial reverse transcriptase step (enzymatic conversion of the RNA to copy DNA) required for subsequent PCR is likely to be problematic. Sensitivity of the reverse transcriptase enzyme to salts, alcohols or phenol remaining from the RNA isolation, and inhibition of the polymerase enzyme Taq by residual reverse transcriptase enzyme are just some of the causes of potentially gross under-estimation of RNA levels in such low copy number samples. Ahern (2007) attempted to quantify $16 \mathrm{~S}$ rRNA from bacteria and Pseudomonads in two cloud water samples and obtained very low apparent levels. She recommended that without extensive initial optimisation, RNA be restricted to use with methods assessing the presence or absence of specific rRNA sequences and not quantification.

\subsubsection{Amplified Ribosomal DNA Restriction Analysis (ARDRA)}

The mixture of PCR products obtained from an aerosol sample can be separated into individual molecules by gene cloning. This involves joining individual PCR products to a self replicating vector which is then transformed into a host cell, usually E. coli. This is plated onto agar and when the host cell divides copies of the recombinant DNA molecule are passed onto the progeny. Following many cell divisions colonies (clones) are produced. Each of these contains a single 16S rDNA sequence from one bacterial cell present in the original mixture. A number of these (generally fifty to several hundred) can then be sequenced and the identity of 
Table 1. Primers used successfully to amplify ice nucleation genes from environmental isolates.

\begin{tabular}{|c|c|c|c|c|}
\hline Allele & $\begin{array}{l}\text { Primers developed (forward \& reverse positions from the start } \\
\text { codon of the IN gene) }\end{array}$ & $\begin{array}{l}\text { Annealing } \\
\text { temp }\left({ }^{\circ} \mathrm{C}\right)\end{array}$ & $\begin{array}{l}\text { No. of iso- } \\
\text { lates used }\end{array}$ & Reference \\
\hline \multirow[t]{2}{*}{$\operatorname{ina\mathrm {A}}$} & 5-ATGAGTGTATCGCTATTGAAACTCATGG-3 (221-248) & 58 & 1 & Dimos et al. (2006) \\
\hline & 5-ACGATATTATTGTCCTCATCCATCTGG-3 (3924-3950) & & & \\
\hline \multirow[t]{4}{*}{$\operatorname{ina} \mathrm{W}$} & 5-GCGGTCTGGTATGGCCTATTT-3 (59-79) & 47 & $2^{*}$ & Castrillo et al. (2000) \\
\hline & 5-CCGGCGTATCGCTATTGTCC-3 (3588-3607) & & & \\
\hline & 5-AACCAGATTGCGAGTCATAAG-3 (3052-3072) & 59 & $1 * *$ & Ahern (2007) \\
\hline & 5-CATGGCTGAATCTGAGACTGG-3 (3612-3632) & & & \\
\hline \multirow[t]{4}{*}{ inaZ } & 5-GAGAATGGTCTGGTCGGTTTACTGTGG-3 (124-150) & 58 & 5 & Dimos et al. (2006) \\
\hline & 5-TCAACACCGTTCTCACCCGTTCTGG-3 (3494-3518) & & & \\
\hline & 5'-CAAGTGTCACGTTACCGGTG-3' (404-423) & & & \\
\hline & 5'-ATCCAGTCATCGTCCTCGTC-3' (3571-3590) & 55 & $3 *$ & Castrillo et al. (2000) \\
\hline inaZ/K/V/W/Y & Primers targeting core and C-terminal under development & - & $\sim 100$ & Guilbaud et al. (2007) \\
\hline
\end{tabular}

* Product shown in paper $\sim 1 \mathrm{~kb}$ larger than expected. Also inaW amplification of isolate 26 (used by Castrillo et al., 2000) unable to be repeated by Ahern (2007).

** Exceptionally strong product using aforementioned isolate 26 but amplification unsuccessful when used on a range of other $P$. fluorescens isolates (Caroline Guilbaud, personal communication).

members of the community determined. To enable a larger number of clones to be analysed and so increase coverage each can first be re-amplified using vector specific primers and the product cut with a restriction enzyme to generate a banding pattern of between 2 and 8 fragments for each clone (see Sect. 3.3.4). The choice of enzyme is crucial and has been assessed systematically (Moyer et al., 1996). The patterns are then sorted on the basis of the number and size of fragments into operational taxonomic units (OTUs) and representatives from each group sequenced (Moffett et al., 2003; Ahern et al., 2007). ARDRA is fairly labour intensive but relatively inexpensive and combined with targeted sequencing provides the identity of the dominant members of a community

\subsubsection{Terminal Restriction Fragment Length Poly- morphisms (T-RFLP) and Ribosomal Intergenic Spacer Analysis (RISA)}

For the broad characterization of microbial community structure and diversity, T-RFLP can be applied. It also gives a very rough estimate of relative abundances. As T-RFLP was originally designed for bacteria, we outline here the method using bacteria as the default. T-RFLP can, however, also be applied to other organisms like fungi, where the ITS regions, the mostly non-coding spacer regions between adjacent rRNA genes, are the most informative.

A PCR is performed in which one primer is fluorescently labelled. The amplification products are then digested with a restriction enzyme which cuts the DNA at a defined site. For example, MspI cuts the sequence ${ }_{\text {GGCC }}^{\text {CCGG }}$. The position of the cut site varies among the different bacterial groups and therefore the length of the labelled terminal fragment varies.

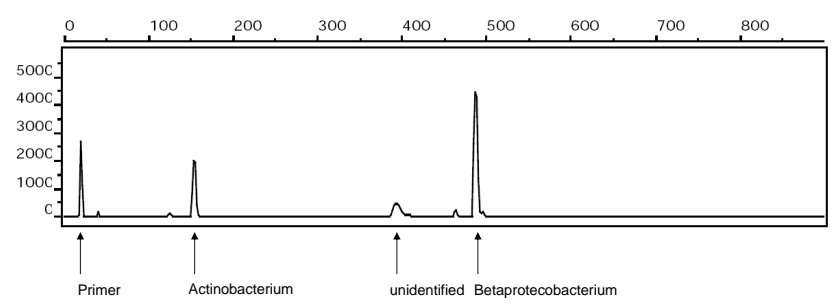

Fig. 2. T-RFLP trace of the bacteria (16S rRNA gene digested with MspI) in an aerosol sample (PM2.5) taken in Munich in spring, 2005.

After digestion the fluorescently-labelled end fragments are separated by electrophoresis and their lengths (position of the peak along the profile) and intensities (peak area) can be calculated (Fig. 2).

The diversity represented by a T-RFLP profile is highly dependant upon choice of enzyme and the part of the gene used to generate the terminal fragments. For example, $M s p \mathrm{I}$ is particularly good when used with the front of the $16 \mathrm{~S}$ rRNA gene, using the primer $27 \mathrm{f}$ (confirmed on aerosols by Després et al. (2007) and rain water by Helen Ahern, unpublished data). Primer and enzyme combinations can be tested on personal and public 16S rRNA databases using T-RFLP simulation programs, available at MiCA 3 (http:// mica.ibest.uidaho.edu/) and the Ribosomal Database Project II (http://rdp.cme.msu.edu, release 8.1). Using MiCA 3 the following enzymes were predicted to produce the most diverse profile using the front of the $16 \mathrm{~S}$ gene to generate terminal fragments: Hpy188III, HhaI, ScrFI, Hpy $188 \mathrm{I}$ and BfaI (MspI is in the top 10). One complication can be clusters of peaks. This is caused because the length between the labelled primer and a site that is cut can naturally vary slightly 
between species. The result is a mound of peaks which can be difficult to resolve.

If the PCR products are simultaneously cloned and sequenced the size of the terminal fragment each will produce can be calculated, and so each can be tentatively assigned to a T-RF peak. Thus the relative abundance of taxonomically identified bacterial groups can be judged. However, one should keep in mind that different bacterial groups can have the same restriction site and thus the relative amount can be misleading. Also, since different bacteria possess from 1-15 copies of the 16S rRNA gene the size of the peak can only be considered a semi-quantitative guide to abundance.

Although the $16 \mathrm{~S}$ region is particularly good for T-RFLP analysis it also has drawbacks. At least in air samples, bacteria, fungi and plant material are all sampled simultaneously. As the DNA is extracted in one step, chloroplast 16S rDNA is often co-amplified with bacterial $16 \mathrm{~S}$ rDNA since, due to their common origin, they possess many similarities. This has to be considered in the interpretation.

In comparison with the analysis of clone libraries (ARDRA or direct sequencing of clones), T-RFLP is much faster and cheaper. If the former approach is used, $\geq 300$ clones have to be analyzed to obtain reliable estimates of abundances and diversity levels in diverse samples. Thus for a fast overview of the diversity and relative abundances T-RFLP is highly useful. For a detailed analysis, however, subsequent sequence analysis is necessary to, for example, detect species that produce the same T-RF peak.

Another useful approach to obtain a broad profile of community diversity is Ribosomal Intergenic Spacer Analysis (RISA or ARISA when automated). This measures the length of the gap between the 16S and 23S rRNA genes, which can vary from 150 to 1550 bp (Scheinert et al., 1996; Maron et al., 2005). By amplifying the region in all or a specific group of bacteria in a sample then separating the products by electrophoresis a profile of peaks will be generated. Maron et al. (2005) performed ARISA on two air samples, revealing both to be highly diverse and distinct. As with T-RFLP, but to a lesser degree, one peak may be comprised of products of several species. But unlike T-RFLP, a single species may produce two or sometimes three peaks. This is because the gap between the $16 \mathrm{~S}$ and $23 \mathrm{~S}$ genes can differ in different ribosomal RNA operons in a bacterium's genome. In the five fully sequenced strains of Pseudomonas fluorescens and $P$. syringae, four have spacer regions all of one length (but unique for each strain) while one $P$. syringae strain has two (534 and $550 \mathrm{bp}$ ). Comparing eight Pseudomonads, Danovaro et al. (2006) found only one with two peaks in ARISA, and clearly demonstrated the method's superiority over T-RFLP with this genus. Even though ARISA has inherently greater resolving power (ie, number of peaks produced per sample; see Danovaro et al., 2006), both greatly underestimate total diversity in diverse samples (Bent et al., 2007).

Biogeosciences, 6, 721-737, 2009

\subsubsection{Denaturing/Thermal Gradient Gel Electrophore- sis (D/TGGE)}

The mixture of PCR products can also be separated by being run on a gel which separates products on the basis of their internal sequence, which affects their melting behaviour. PCR products are electrophoresed on a gel with a linearly increasing gradient of chemicals (DGGE) or temperature (TGGE). The fragments remain double stranded until the denaturing conditions cause melting of certain regions (domains). Products with the lowest melting temperature domains (those with runs of A-T base pairs) melt first and the branching of the molecule causes a sharp decrease in mobility. As these molecules continue to move slowly into higher concentrations of denaturant, additional domains undergo strand dissociation. Single base changes in any of these domains will alter their melting temperature and so will lead to different mobilities. However when the most stable domains melt the fragment undergoes complete dissociation and the resolving power of the gel is lost. To overcome this problem one of the PCR primers has a GC-rich "clamp" attached to it which resists the denaturing conditions of the gel (Muyzer and Smalla, 1998; Myers et al., 1985).

The end result is a multiple-banded fingerprint of the community which is very useful for comparisons to determine if there is any value in pursuing a more detailed analysis. This is especially true for less complex communities such as those in extreme environments. Diverse samples may produce too many bands to be resolved. In addition individual bands can also be cut from the gel and sequenced. One limitation is that only PCR products up to $500 \mathrm{bp}$ can be separated efficiently. This limits the precision of subsequent identification based on sequence comparison. In addition single bacteria can produce more than one band and resolution may be insufficient as products with different sequences may migrate to the same position on the gel (Ranjard et al., 2000), although to a lesser extent than T-RFLP.

An analogous technique to T/DGGE, in terms of technique and gel product, is Single Strand Conformation Polymorphism (Schwieger and Tebbe, 1998). Smalla et al. (2007) compared DGGE, T-RFLP and SSCP for their ability to fingerprint DNA extracts from four soils. T-RFLP and SSCP produced tighter clusters of replicate soil samples than DGGE. Methodologically too, SSCP may be preferable to T/DGGE since the equipment is cheaper, it is easier to find compatible primers and it does not need a gradient gel (Birgit Sattler, personal communication).

\subsubsection{Quantitative PCR (qPCR)}

A more recent technique, quantitative real-time PCR, can be used to not only detect but also determine the number of copies of a chosen gene in a sample. As with standard PCR, depending on the gene and primers used the target for quantification can be broad (e.g., all bacteria using the $16 \mathrm{~S} \mathrm{rDNA}$ ) 
Table 2. Dominant bacterial groups found in studies using direct DNA-based methods.

\begin{tabular}{|c|c|c|c|c|}
\hline Sampling site & Sampling date/s & Dominant bacterial groups & Analysis method & Reference \\
\hline $\begin{array}{l}\text { Urban aerosol, } \\
\text { Salt Lake City, UT }\end{array}$ & Oct 2000 & $\begin{array}{l}25 \% \text { High } \mathrm{G}+\mathrm{C} \text { Gram }+\mathrm{ve} \\
23 \% \text { Low } \mathrm{G}+\mathrm{C} \text { Gram +ve } \\
23 \% \alpha, \beta, \gamma, \delta \text { Proteobacteria }\end{array}$ & Cloning \& sequencing & Radosevich et al., 2002 \\
\hline $\begin{array}{l}\text { Urban aerosol, } \\
\text { San Antonio \& Austin, TX }\end{array}$ & May-Aug 2003 & $\begin{array}{l}35 \% \text { Low G+C Gram +ve Bacilli; } \\
\text { thereafter high diversity }\end{array}$ & $\begin{array}{l}\text { Cloning \& sequencing; } \\
\text { Gene chip }\end{array}$ & Brodie et al., 2007 \\
\hline $\begin{array}{l}\text { Urban (but rural nearby) aerosol, } \\
\text { Livermore, CA }\end{array}$ & Aug 2000 & $\begin{array}{l}\text { Great majority Low G+C Gram +ve of Bacillus- } \\
\text { Lactobacillus-Streptococcus subdivision }\end{array}$ & $\begin{array}{l}\text { Cloning \& sequencing; } \\
\text { Gene chip }\end{array}$ & Wilson et al., 2002 \\
\hline $\begin{array}{l}\text { Rural aerosol, } \\
\text { south of Paris, France }\end{array}$ & Mar \& May 2003 & $\begin{array}{l}60 \% \text { Proteobacteria } \\
13 \% \text { Low G+C Gram +ve } \\
11 \% \text { High G+C Gram +ve }\end{array}$ & Cloning \& sequencing & Maron et al., 2005 \\
\hline $\begin{array}{l}\text { Urban, rural \& } \\
\text { high alpine aerosol, } \\
\text { South Germany }\end{array}$ & $\begin{array}{l}\text { Sep } 2003 \text {, } \\
\text { Jun-Sep 2004, } \\
\text { Feb-May 2005 }\end{array}$ & $\begin{array}{l}62-92 \% \gamma \text { then } \beta \text { Proteobacteria } \\
(87-95 \% \text { Proteobacteria using T-RFLP peak } \\
\text { intensities) } \\
19 \% \text { High G+C Gram +ve }\end{array}$ & $\begin{array}{l}\text { Cloning \& sequencing; } \\
\text { T-RFLP }\end{array}$ & Després et al., 2007 \\
\hline $\begin{array}{l}\text { Coastal rural cloud \& rain, } \\
\text { NW Scotland, UK }\end{array}$ & Oct 2003 & $\begin{array}{l}36 \% \gamma, \beta \text { then } \alpha \text { Proteobacteria } \\
\text { (the most abundant five OTUs) }\end{array}$ & Cloning \& sequencing & Ahern et al., 2007 \\
\hline $\begin{array}{l}\text { Surface snow, } \\
\text { Tyrolean Alps, Austria }\end{array}$ & May 1995 & $\begin{array}{l}40 \% \beta \text { Proteobacteria } \\
\text { (of total DAPI counts) }\end{array}$ & $\begin{array}{l}\text { In situ hybridisation for } \beta \\
\text { Proteobacteria; } \\
\text { DAPI staining }\end{array}$ & Alfreider et al., 1996 \\
\hline
\end{tabular}

or narrow (e.g., an ice nucleating species using a specific IN gene). If the number of copies of the gene per cell is known then it can be converted to cell counts or microbial biomass. qPCR is the only practicable method available for accurate quantification of multiple samples, especially those with very low numbers of cells $(<100)$.

The method requires that the accumulation of PCR product be monitored as the reaction proceeds. The number of PCR cycles needed to first detect the product (the threshold cycle) is then used to determine the number of copies present at the start. If there very few target molecules then more replication cycles are needed before the product is first detected (and vice versa). The threshold cycle is proportional to the $\log$ of the initial DNA concentration, and the number of gene copies is determined by reference to a calibration curve generated using DNA from known numbers of cells, spores or quantity of mycelium. Calibration curves are typically linear over at least 5 orders of magnitude. Conversion of $16 \mathrm{~S}$ rRNA gene copy number to cell number can introduce error since different species of bacteria possess from 1-15 copies of the gene per cell (Cole and Girons, 1994); in Pseudomonads it varies from 4-7. Fogel (1999) reported an average of 3.8 copies per cell of the $16 \mathrm{~S}$ gene per bacterial species, and in leachate and nitrifying biofilm we estimated an average of 3.5 .

One approach to monitor product accumulation uses the dye Sybr Green which only fluoresces when it binds to double stranded DNA. A great advantage of using Sybr Green is that it is simple and cheap to convert standard PCR to quantitative. However, reaction optimization is essential to ensure amplification of only the target, since any nonspecific product will also be detected. Primers also com- bine with each other during PCR to form small doublestranded primer-dimers, and fluorescence from these needs to be minimised by measuring fluorescence at a temperature high enough for them to have dissociated. Alternatively, fluorophore-containing DNA probes, such as TaqMan, Hybprobes, molecular beacons and scorpion probes can be added to the reaction mix. These are designed so that they will only fluoresce if they are annealed to the correct target sequence. As the product accumulates, the level of fluorescence increases proportionally. They use different mechanisms to report annealing (eg, bound TaqMan probes are digested by Taq polymerase, freeing the fluorophore from a quencher embedded in the probe) but share several features: they provide very specific and reliable detection of the amplified gene, but require careful design and optimisation, and are more costly and emit less light than Sybr Green.

A potentially major problem for GPCR with environmental samples is PCR bias which can differentially affect the rates of amplification of the samples versus the standards, and cause underestimation of the samples' true gene copy number. The principal problem is from inhibitors co-extracted with the DNA which can inhibit the PCR of each sample to differing degrees (e.g., Grüntzig et al., 2001). Jansson and Leser (2004) noted that the extrapolation to an external standard curve used by qPCR is not well suited to environmental samples because a small variation in the PCR reaction efficiency can produce large differences in product yield in later cycles. An improvement, sigmoidal curve-fitting, has been suggested by Rutledge (2004). Samples can also be spiked with a known number of copies of the targeted gene and the level of inhibition estimated. 
Table 3. Characteristics of single-particle methods that are used for the study of the properties of atmospheric aerosol particles.

\begin{tabular}{|c|c|c|c|c|c|}
\hline \multirow[b]{2}{*}{ Methods } & \multirow[b]{2}{*}{ Size and shape } & \multicolumn{2}{|c|}{ Particle properties that can be studied } & \multirow[b]{2}{*}{$\begin{array}{l}\text { Surface and hygroscopic } \\
\text { properties }\end{array}$} & \multirow[b]{2}{*}{ Advantages and drawbacks } \\
\hline & & Composition & Structure & & \\
\hline $\mathrm{OM}$ & $\sim 0.2 \mu \mathrm{m}$ resolution & $\begin{array}{l}\text { epifluorescent mi- } \\
\text { croscopy for identifying } \\
\text { biological components }\end{array}$ & No & No & low resolution \\
\hline SEM & $\begin{array}{lr}\sim 20 \mathrm{~nm} & \text { resolution } \\
\text { with an } & \text { FEG-SEM; } \\
\text { approximate } & 3-\mathrm{D} \\
\text { morphology } & \text { from } \\
\text { secondary } & \text { electron } \\
\text { images } & \end{array}$ & $\begin{array}{l}\text { elemental analysis with } \\
\text { EDS; semi-quantitative } \\
\text { for light elements }\end{array}$ & No & $\begin{array}{l}\text { ESEM for the study of hydra- } \\
\text { tion/dehydration cycles }\end{array}$ & $\begin{array}{l}\text { can be automated, good statis- } \\
\text { tics; relatively low spatial and } \\
\text { compositional specificity }\end{array}$ \\
\hline TEM & $\begin{array}{l}1 \AA \text { resolution possible; } \\
\text { accurate } \\
\text { dimensional three- } \\
\text { phology from ET (in } \\
\text { vacuum) }\end{array}$ & $\begin{array}{l}\text { elemental analysis with } \\
\text { EDS; elemental anal- } \\
\text { ysis with EELS and } \\
\text { energy-filtered images, } \\
\text { suitable for light ele- } \\
\text { ments in thin particles } \\
(<100 \mathrm{~nm})\end{array}$ & $\begin{array}{l}\text { from electron } \\
\text { diffraction }\end{array}$ & $\begin{array}{l}\text { ETEM for the study of hydra- } \\
\text { tion/dehydration cycles }\end{array}$ & $\begin{array}{l}\text { high spatial specificity for } \\
\text { shape, composition, and } \\
\text { structure; manually operated, } \\
\text { labor-intensive, resulting in } \\
\text { poor statistics }\end{array}$ \\
\hline AFM & $\begin{array}{l}\mathrm{nm} \text { resolution, approx- } \\
\text { imate } 3 \text {-D morphology }\end{array}$ & No & No & $\begin{array}{l}\text { works under ambient condi- } \\
\text { tions, hydration/dehydration } \\
\text { cycles can be studied }\end{array}$ & $\begin{array}{l}\text { mechanical properties of sur- } \\
\text { faces can be studied; labor- } \\
\text { intensive, interpretation of re- } \\
\text { sults ambiguous; no composi- } \\
\text { tional information }\end{array}$ \\
\hline AMS & $\begin{array}{l}\text { particle sizing and indi- } \\
\text { rect shape information } \\
\text { from laser scattering }\end{array}$ & $\begin{array}{l}+ \text { and }- \text { ion fragment } \\
\text { mass compositions; }\end{array}$ & No & $\begin{array}{l}\text { surface composition can be } \\
\text { probed by two-laser AMS; } \\
\text { suitable for heterogeneous } \\
\text { surface chemistry }\end{array}$ & $\begin{array}{l}\text { fast response (down to } \mathrm{ms} \text { ); } \\
\text { extremely good sensitivity and } \\
\text { statistics; specific biogenic } \\
\text { components can be identi- } \\
\text { fied (BAMS); interpretation of } \\
\text { compositions often ambigu- } \\
\text { ous; no image and no struc- } \\
\text { tural information }\end{array}$ \\
\hline
\end{tabular}

AFM: atomic force microscopy; AMS: aerosol mass spectrometry; BAMS: bioaerosol mass spectrometry; ED: electron diffraction; EDS: energy-dispersive X-ray spectrometry; EELS: electron energy-loss spectroscopy; ESEM: environmental scanning electron microscopy; ET: electron tomography; ETEM: environmental transmission electron microscopy; FEG: field-emission gun; OM: optical microscopy; SEM: scanning electron microscopy; TEM: transmission electron microscopy

We have used qPCR on DNA extracted from orographic cloud water (Bowbeat, Scottish borders) to count the total number of $16 \mathrm{~S} \mathrm{rRNA}$ genes (ie, all bacteria) and the number of $16 \mathrm{~S}$ rRNA genes contributed by the Pseudomonads. Detection used Sybr Green I. The total number was around 8300 copies $\mathrm{ml}^{-1}$ cloud water whereas the number contributed by the Pseudomonads was about 150. Provisional analyses indicate that this ratio corresponded reasonably well with the clone frequency of Pseudomonads using ARDRA. qPCR enables rapid investigation of multiple samples for the abundance of any chosen phylogenetic group and key functional genes. Development of primers that will detect and quantify all IN gene alleles is an urgent priority.

\subsubsection{Dominant bacteria in bioaerosols using DNA- based methods}

While culture-based studies of atmospheric aerosols indicate dominance by Gram-positive bacteria (e.g., Kellogg and Griffin, 2006) direct DNA-based methods reveal a more diverse assemblage, with an intriguing suggestion of a predom- inance by the High and Low $\mathrm{G}+\mathrm{C}$ Gram-positives in the USA but a higher relative abundance of the Proteobacteria (especially the $\beta$ and $\gamma$ subdivisions) in Europe (Table 2). Using culturing, Amato et al. (2007) found that Gram-positives are more abundant than the Proteobacteria in winter, and vice versa, but no such clear trend is apparent from these studies.

\section{Conclusions}

Detection, quantification and characterization of particles of biological origin in aerosols, including microorganisms, pollen, plankton, plant and animal debris, etc., is necessary to understand the role and the effects of bioaerosols in a number of processes, from physical effects, such as ice-nucleation, to atmospheric chemistry, ecology, and health effects. It is generally believed that the biosphere (for example vegetation) influences and perhaps drives climate changes. Bioaerosols have been recently suggested as a potentially important factor, but their role in climate remains undetermined. What is the contribution of different 
bioaerosols to significant atmospheric processes such as ice nucleation or cloud condensation? To address these, we need a clearer picture of the composition, seasonal fluctuation, regional diversity and evolution of bioaerosols. In this paper we have described and reviewed current and emerging methods for the characterisation of bioaerosols. Most were developed to monitor human, animal and plant health hazards, and therefore were designed to detect one or a few groups of organisms. For example, methods to characterize microorganisms in bioaerosols have too often relied on isolation and culture. It now seems that reports of numbers of microorganisms in bioaerosols where the culture method was used may have grossly underestimated the true number by one to four orders of magnitude. Meteorologists often question the effect of biotic components in aerosols on precipitation, an argument based on published numbers of bacteria and fungi in atmospheric samples which were considered too small to have an impact. However, estimations were in most cases produced using culture methods. Even less work has been done to determine the number of plant, virus or animal fragments in bioaerosols and very little is known about their potential effect on atmospheric processes. For example, what might be the effect of secondary bioaerosol components (e.g. protein crystals) which may no longer be associated with nucleic acids? Or particles of mixed composition? From a meteorological perspective, it is important to know the actual composition of a bioaerosol in order to evaluate or model the role of individual components as ice nuclei or cloud condensation nuclei which potentially trigger precipitation. To this end, only pollen and certain bacteria have been characterized as ice nuclei; the ice nucleation property of certain bacteria has been well studied, but for pollen and other biological ice nuclei nothing is known about the factors that determine their ice nucleation properties. It is therefore important that future research is coordinated, in characterizing the composition, seasonal fluctuation and evolution of ice nucleation and cloud condensation components (starting perhaps with the most abundant), toward understanding the role of the individual components. We would like to point out that significant progress in characterizing the role of bioaerosols in atmospheric processes could be achieved with a reverse strategy: characterize the biological (or non-biological) nature of particles that already have exhibited interesting properties such as ice nucleation by using sampling methods for in situ isolation of ice nuclei from aerosols near the ground or in the atmosphere. New methods of bioaerosol characterization that can be integrated into methods and equipment used in cloud physics should be developed, to serve the integration of research from the various disciplines of microbiology, meteorology, molecular biology, cloud physics and cloud chemistry.

\section{Edited by: M. Dai}

\section{References}

Ahern, H. E.: Cloud Borne Bacteria: Community Composition and Potential Impact on Atmospheric Nucleation, PhD Thesis, University of East London, 2007.

Ahern, H. E., Walsh, K. A., Hill, T. C. J., and Moffett B. F.: Fluorescent pseudomonads isolated from Hebridean cloud and rain water produce biosurfactants but do not cause ice nucleation, Biogeosciences, 4, 115-124, 2007, http://www.biogeosciences.net/4/115/2007/.

Alfreider, A., Pernthaler, J., Amann, R., Sattler, B., Glockner, F. O., Wille, A., and Psenner, R.: Community analysis of the bacteria assemblages in winter cover and pelagic layers of a high mountain lake using in situ hybridization, Appl. Environ. Microb., 62, 2138-2144, 1996.

Amann, R., and Ludwig, W.: Ribosomal RNA-targeted nucleic acid probes for studies in microbial ecology, FEMS Microbiol. Rev., 24, 555-565, 2000.

Amato, P., Menager, M., Sancelme, M., Laj, P., Mailhot, G. D., and Delort, A.-M.: Microbial population in cloud water at the Puy de Dôme: implications for the chemistry of clouds, Atmos. Env., 39, 4143-4153, 2005.

Amato, P., Parazols, M., Sancelme, M., Laj, P., Mailhot, G., and Delort, A.-M.: Microorganisms isolated from the water phase of tropospheric clouds at the Puy de Dôme: major groups and growth abilities at low temperatures, FEMS Microbiol. Ecol., 59, 242-54, 2007.

Amato, P., Parazols, M., Sancelme, M., Mailhot, G., Laj, P., and Delort, A.-M.: An important source of micro-organisms for cloud water at the Puy de Dôme (France), Atmos. Environ., 41, 82538263, 2007.

Anderson, J. R., Aggett, F. J., Buseck, P. R., Germani, M. S., and Shattuck, T. W.: Chemistry of individual aerosol particles from Chandler, Arizona, an arid urban environment, Environ. Sci. Technol., 22(7), 811-818, 1988.

Andreeva, I. S., Belan, B. D., Borodulin, A. I., Buryak, G. A., Zhukov, V. A., Panchenko, M. V., Penenko, V. V., Petrishchenko, V. A., and Safatov, A. S.: Variability of the content of live microorganisms in the atmospheric aerosol in southern regions of Western Siberia, Doklady Biol. Sci., 381, 530-534, 2001.

Ariya, P. A., Nepotchatykh, O., Igntova, O., and Amyot, M.: Microbiological degradation of organic compounds in the atmosphere, Geophys. Res. Lett., 29, 341-344, 2002.

Barkay, Z., Teller, A., Ganor, E., Levin, Z., and Shapira, Y.: Atomic force and scanning electron microscopy of atmospheric particles, Microsc. Res. Techniq., 68(2), 107-114, 2005.

Bauer, H., Kasper-Giebl, A., Loflund, H., Giebl, H., Hitzenberger, R., Zibuschka, F., and Puxbaum, H.: The contribution of bacteria and fungal spores to the organic carbon content of cloud water, precipitation and aerosols, Atmos. Res., 64, 100-119, 2002.

Beddows, D. C. S. and Telle, H. H.: Prospects of real-time singleparticle biological aerosol analysis: A comparison between laserinduced breakdown spectroscopy and aerosol time-of-flight mass spectrometry, Spectrochim. Acta B, 60(7-8), 1040-1059, 2005.

Bent, S. J., Pierson, J. D., and Forney, L. J.: Measuring species richness based on microbial community fingerprints: the emperor has no clothes, Appl. Environ. Microb., 73, 2399-2401, 2007.

Birenzvige, A., Eversole, J., Seaver, M., Francesconi, S., Valdes, E., and Kulaga, H.: Aerosol characteristics in a subway environment, Aerosol Sci. Tech., 37, 210-220, 2003. 
Blando, J. D., Porcja, R. J., Li, T. H., Bowman, D., Lioy, P. J., and Turpin, B. J.: Secondary formation and Smokey Mountain organic aerosol: an examination of aerosol polarity and functional group composition during SEAVS, Environ. Sci. Technol., 32, 604-613, 1998.

Brodie, E. L., DeSantis, T. Z., Parker, J. P. M., Zubietta, I. X., Piceno, Y. M., and Andersen, G. L.: Urban aerosols harbor diverse and dynamic bacterial populations, Proc. Natl. Acad. Sci. USA, 104, 299-304, 2007.

Burge, H. A.: Bioaerosol investigations, in: Bioaerosols, edited by: Burge, H. A., CRC Press, Boca Raton, FL, USA, 1-23, 1995.

Castrillo, L. A., Lee, Jr. R. E., Lee, M. R., and Rutherford, S. T.: Identification of ice-nucleating active Pseudomonas fluorescens strains for biological control of overwintering Colorado potato beetles (Coleoptera: Chrysomelidae), J. Econ. Entomol., 226233, 2000

Chapman, M. D.: Analytical methods: immunoassays, in: Bioaerosols, edited by: Burge, H. A., CRC Press, Boca Raton, FL, USA, 235-248, 1995.

Chen, Y. Z., Shah, N., Huggins, F. E., and Huffman, G. P.: Characterization of ambient airborne particles by energy-filtered transmission electron microscopy, Aerosol Sci. Tech., 39(6), 509518,2005

Chi, M.-C. and Li, C.-S.: Fluorochrome and Fluorescent In Situ Hybridization to monitor bioaerosols in swine buildings, Aerosol Sci. Tech., 39, 1101-1110, 2005.

Christner, B. C., Cai, R., Morris, C. E., Mc Carter, K. S., Foreman, C. M., Skidmore, M. L., Montross, S. N., and Sands, D. C.: Geographic, seasonal, and precipitation chemistry influence on the abundance and activity of biological ice nucleators in rain and snow, Proc. Natl. Acad. Sci. USA, 105, 18854-18859, 2008.

Christner, B. C., Morris, C. E., Foreman, C. M., Cai, R., and Sands, D. C.: Ubiquity of biological ice nucleators in snowfall, Science, 319, 1214, 2008.

Christner, B. C., Mosley-Thompson, E., Thompson, L. G., and Reeve, J. N.: Isolation of bacteria and 16S rDNAs from Lake Vostok accretion ice, Environ. Microb., 3, 570-577, 2001.

Cole, S. T. and Girons, I. S.: Bacterial genomics, FEMS Microbiol. Rev., 14, 139-160, 1994.

Cote, V., Kos, G., Mortazavi, A., and Ariya, P. A.: Microbial and "de novo" transformation of dicarboxylic acids by three airborne fungi, Sci. Total Environ. 390(2-3), 530-537, 2008.

Danovaro, R., Luna, G. M., Dell'Anno, A., and Pietrangeli, B.: Comparison of two fingerprinting techniques, Terminal Restriction Fragment Length Polymorphism and Automated Ribosomal Intergenic Spacer Analysis, for determination of bacterial diversity in aquatic environments, Appl. Environ. Microb., 72, 59825989, 2006.

de Hoog, J., Osan, J., Szaloki, I., Eyckmans, K., Worobiec, A., Ro, C. U., and Van Grieken, R.: Thin-window electron probe Xray microanalysis of individual atmospheric particles above the North Sea, Atmos. Environ. 39(18), 3231-3242, 2005

Decesari, S., Facchini, M. C., Fuzzi, S., and Tagliavini, E.: Characterization of Water-Soluble Organic Compounds in Atmospheric Aerosol: A New Approach, J. Geophys. Res.-Atmos., 105(D1), 1481-1489, 2000.

Decesari, S., Facchini, M. C., Matta, E., Lettini, F., Mircea, M., Fuzzi, S., Tagliavini, E., and Putaud, J. P.: Chemical features and seasonal trend of water soluble organic compounds in the Po
Valley fine aerosol, Atmos. Environ., 35, 3691-3699, 2001. Decesari, S., Mircea, M., Cavalli, F., Fuzzi, S., Moretti, F., Tagliavini, E., and Facchini, M. C. : Source Attribution of WaterSoluble Organic Aerosol by Nuclear Magnetic Resonance Spectroscopy, Environ. Sci. Tech., 41, 2479-2484, 2007.

Després, V. R., Nowoisky, J. F., Klose, M., Conrad, R., Andreae, M. O., and Pöschl, U.: Characterization of primary biogenic aerosol particles in urban, rural, and high-alpine air by DNA sequence and restriction fragment analysis of ribosomal RNA genes, Biogeosciences, 4, 1127-1141, 2007, http://www.biogeosciences.net/4/1127/2007/.

Dimos, D., Kallimanis, A., Perisynakis, A., Chatziloukas, E., and Drainas, C.: A contribution to the analysis of the genetic diversity of bacterial ice nucleation genes in Hellenic niches, HSBMB Newsletter, 53, 66-67, 2006.

Ebert, M., Inerle-Hof, M., and Weinbruch, S.: Environmental scanning electron microscopy as a new technique to determine the hygroscopic behaviour of individual aerosol particles, Atmos. Environ., 36(39-40), 5909-5916, 2002.

Ebert, M., Weinbruch, S., Hoffmann, P., and Ortner, H. M. The chemical composition and complex refractive index of rural and urban influenced aerosols determined by individual particle analysis, Atmos. Environ., 38(38), 6531-6545, 2004.

Fogel, G., Collins, C., Li, J., and Brunk, C.: Prokaryotic genome size and SSU rDNA copy number: estimation of relative abundance from a mixed population, Microbial Ecol., 38, 93-113, 1999.

Friedbacher, G., Grasserbauer, M., Meslmani, Y., Klaus, N., and Higatsberger, M. J.: Investigation of environmental aerosol by atomic force microscopy, Anal. Chem., 67, 1749-1754, 1995.

Gilardoni, S., Russell, L. M., Sorooshian, A., Flagan, R. C., Seinfeld, J. H., Bates, T. S., Quinn, P. K., Allan, J. D., Williams, B., Goldstein, A. H., Onasch, T. B., and Worsnop, D. R.: Regional variation of organic functional groups in aerosol particles on four US east coast platforms during the International Consortium for Atmospheric Research on Transport and Transformation 2004 campaign, J. Geophys. Res.-Atmos., 112, D10S27, doi:10.1029/2006JD007737, 2007.

Grüntzig, V. Nold, S. C., Zhou, Z., and Tiedje, J. M.: Pseudomonas stutzeri nitrite reductase gene abundance in environmental samples measured by real-time PCR, Appl. Environ. Microb., 67, 760-768, 2001.

Guilbaud, C., Ahern, H., Dominguez, H., Glaux C., Moffett, B., Hill, T., and Morris, C.: Detecting ice nucleating bacteria in environmental samples using PCR of the gene conferring ice nucleation activity. Paper presented at the IUGG's Earth: Our Changing Planet Symposium, Perugia, Italy, July, 2007.

Jaenicke, R.: Abundance of cellular material and proteins in the atmosphere, Science, 308, 73, 2005.

Jansson, J. and Leser, T: Quantitative PCR of environmental samples, in: Molecular Microbiology Manual, 2nd Edition, Kluwer Academic Publishers, The Netherlands, 445-464, 2004.

Kaegi, R. and Holzer, L.: Transfer of a single particle for combined ESEM and TEM analyses, Atmos. Environ., 37(31), 4353-4359, 2003.

Katrinak, K. A., Rez, P., and Buseck, P. R.: Structural variations in individual carbonaceous particles from an urban aerosol, Environ. Sci. Tech., 26, 1967-1976, 1992.

Kellogg, C. A. and Griffin, D. W.: Aerobiology and the global trans- 
port of desert dust, Trends Ecol. Evol., 21, 638-644, 2006.

Kemp, B. M., Monroe, C., and Smith, D. G.: Repeat silica extraction: a simple technique for the removal of PCR inhibitors from DNA extracts, J. Archaeol. Sci., 33, 1680-1689, 2006.

Kis, V. K., Pósfai, M., and Labar, J. L.: Nanostructure of atmospheric soot particles, Atmos. Environ., 40(29), 5533-5542, 2006.

Knut, R., Moen, B., Drømtorp, S. M., and Holck, A. L.: Use of ethidium monoazide and PCR in combination for quantification of viable and dead cells in complex samples, Appl. Environ. Microb., 71, 1018-1024, 2004.

Köllensperger, G., Friedbacher, G., Kotzick, R., Niessner, R., and Grasserbauer, M.: In-situ atomic force microscopy investigation of aerosols exposed to different humidities, Fresen. J. Anal. Chem., 364, 296-304, 1999.

Krueger, B. J., Grassian, V. H., Iedema, M. J., Cowin, J. P., and Laskin, A.: Probing heterogeneous chemistry of individual atmospheric particles using scanning electron microscopy and energydispersive X-ray analysis, Anal. Chem., 75(19), 5170-5179, 2003.

Laskin, A., Cowin, J.P., and Iedema, M.J.: Analysis of individual environmental particles using modern methods of electron microscopy and X-ray microanalysis. J. Electron Spectrosc., 150(23), 260-274, 2006.

Liu, X. D., Zhu, J., Van Espen, P., Adams, F., Xiao, R., Dong, S. P., Li, Y. W.: Single particle characterization of spring and summer aerosols in Beijing: Formation of composite sulfate of calcium and potassium, Atmos. Environ., 39(36), 6909-6918, 2005.

Lighthart, B.: The ecology of bacteria in the alfresco atmosphere, FEMS Microbiol. Ecol., 23, 263-274, 1997.

Lundheim, R.: Physiological and ecological significance of biological ice nucleators, Phil. Trans. R. Soc. Lond. B, 357, 937-943, 2002.

Margulies, M., Egholm, M., Altman, W. E., Attiya, S., Bader, J. S., Bemben, L. A., Berka, J., Braverman, M. S., Chen, Y.-J., Chen, Z., Dewell, S. B., Du, L., Fierro, J. M., Gomes, X. V., Godwin, B. C., He, W., Helgesen, S., Ho, C.H., Irzyk, G. P., Jando, S. C., Alenquer, M. L. I., Jarvie, T. P., Jirage, K. B., Kim, J.-B., Knight, J. R., Lanza, J. R., Leamon, J. H., Lefkowitz, S.M., Lei, M., Li, J., Lohman, K. L., Lu, H., Makhijani, V. B., McDade, K. E., McKenna, M. P., Myers, E. W., Nickerson, E., Nobile, J. R., Plant, R., Puc, B. P., Ronan, M. T., Roth, G. T., Sarkis, G.J., Simons, J. F., Simpson, J. W., Srinivasan, M., Tartaro, K. R., Tomasz, A., Vogt, K. A., Volkmer, G. A., Wang, S. H., Wang, Y., Weiner, M. P., Yu, P., Begley, R. F., and Rothberg, J. M..: Genome sequencing in microfabricated high-density picolitre reactors, Nature, 437, 376-380, 2005.

Maria, S. F., Russell, L. M., Turpin, B. J., Porcja, R. J., Campos, T. L., Weber, R. J., and Huebert, B. J.: Source Signatures of Carbon Monoxide and Organic Functional Groups in Asian Pacific Regional Aerosol Characterization Experiment (ACE-Asia) Submicron Aerosol Types, J. Geophys. Res.-Atmos., 108, 2003.

Maria, S. F., Russell, L. M., Turpin, B. J., and Porcja, R. J.: FTIR measurements of functional groups and organic mass in aerosol samples over the Caribbean, Atmos. Environ., 36, 5185-5196, 2002.

Marie, D., Brussaard, C. P. D., Thyrhaug, R., Bratbak, G., and Vaulot, D.: Enumeration of marine viruses in culture and natural samples by flow cytometry, Appl. Environ. Microb., 65, 45-52,
1999.

Maron, P., Lejon, D., Carvalho, E., Bizet, K., Lemanceau, P. Ranjard, L., and Mougel, C.: Assessing genetic structure and diversity of airborne bacterial communities by DNA fingerprinting and 16S rDNA clone library, Atmos. Env., 39, 3687-3695, 2005.

Matthias-Maser, S. and Jaenicke, R.: Examination of atmospheric bioaerosol particles with radii $>0.2 \mu \mathrm{m}$. J. Aerosol Sci., 25, 1605-1613, 1994.

Maynard, A. D.: The application of electron-energy-loss spectroscopy to the analysis of ultrafine aerosol-particles, J. Aerosol Sci., 26(5), 757-777, 1995.

Maynard, A. D., Ito, Y., Arslan, I., Zimmer, A. T., Browning, N., and Nicholls, A.: Examining elemental surface enrichment in ultrafine aerosol particles using analytical scanning transmission electron microscopy, Aerosol Sci. Tech., 38(4), 365-381, 2004.

Moffett, B. F., Nicholson, F. A., Uwakwe, N. C., Chambers, B. J., Harris, J. A., and Hill, T. C. J.: Zinc contamination decreases the bacterial diversity of agricultural soil, FEMS Microbiol. Ecol. 43, 13-19, 2003.

Moyer C. L., Tiedje J. M. Dobbs, F. C., and. Karl D. M.: A computer-simulated restriction fragment length polymorphism analysis of bacterial small-subunit rRNA genes: efficacy of selected tetrameric restriction enzymes for studies of microbial diversity in nature, Appl. Environ. Microb., 62, 2501-2507, 1996.

Murphy, D. M., Cziczo, D. J., Froyd, K. D., Hudson, P. K., Matthew, B. M., Middlebrook, A. M., Peltier, R. E., Sullivan, A., Thomson, D. S., and Weber, R. J.: Single-particle mass spectrometry of tropospheric aerosol particles, J. Geophys. Res.-Atmos., 111(D23), D23S32, doi:10.1029/2006JD007340, 2006.

Muyzer G. and Smalla, K.: Application of denaturing gradient gel electrophoresis and temperature gradient gel electrophoresis in microbial molecular ecology, A. Van Leeuw., J. Microb., 73, 127-141, 1998.

Myers, M. R., Fischer, S. G., Maniatis, T., and Lerman, L. S.: Modification of the melting properties of duplex DNA by attachment of a GC-rich DNA sequence as determined by denaturing gradient gel electrophoresis, Nucl. Acid. Res., 13, 3111-3129, 1985.

Nemecek-Marshall, M., Laduca, R., and Fall, R.: High level expression of ice nuclei in Pseudomonas syringae strain is induced by nutrient limitation and low temperature, J. Bacteriol., 175, 40624070, 1993.

Niemi, J. V., Saarikoski, S., Tervahattu, H., Makela, T., Hillamo, R., Vehkamaki, H., Sogacheva, L., and Kulmala, M.: Changes in background aerosol composition in Finland during polluted and clean periods studied by TEM/EDX individual particle analysis, Atmos. Chem. Phys., 6, 5049-5066, 2006, http://www.atmos-chem-phys.net/6/5049/2006/.

Noble, R. T., and Fuhrman, J. A.: Use of SYBR Green I for rapid epifluorescence counts of marine viruses and bacteria, Aquat. Microb. Ecol., 14, 113-118, 1998.

Nocker, A., Cheung, C.-Y., and Camper A. K.: Comparison of propidium monoazide with ethidium monoazide for differentiation of live vs. dead bacteria by selective removal of DNA from dead cells, J. Microbiol. Methods, 67, 310-320, 2006.

O'Brien, R. D. and Lindow, S. E.: Effect of plant species and environmental conditions on ice nucleation activity of Pseudomonas syringae on leaves, Appl. Environ. Microb., 54, 2281-2286, 1988.

Osan, J., Szaloki, I., Ro, C. U., and Van Grieken, R.: Light element 
analysis of individual microparticles using thin-window EPMA, Mikrochim. Acta, 132(2-4), 349-355, 2000.

Peccia, J. and Hernandez, M.: Incorporating polymerase chain reaction-based identification, population characterization, and quantification of microorganisms into aerosol science: a review, Atmos. Env., 40, 3491-3961, 2006.

Pernthaler, A., Pernthaler, J., and Amann, R.: Fluorescent in situ hybridisation and catalyzed reported deposition for the identification of marine bacteria, Appl. Environ. Microb., 68, 30943101, 2002.

Pernthaler, J. Glöckner, F.-O., Unterholzner, S., Alfreider, A., Psenner, R., and Amann, R.: Seasonal community and population dynamics of pelagic bacteria and Archaea in a high mountain lake, Appl. Environ. Microb., 64, 4299-4306, 1998.

Pósfai, M., Anderson, J. R., Buseck, P. R., Shattuck, T. W., and Tindale, N. W.: Constituents of a Remote Pacific Marine Aerosol: A TEM Study Atmos. Environ., 28, 1747-1756, 1994.

Pósfai, M., Anderson, J. R., Buseck, P. R., and Sievering, H.: Compositional variations of sea-salt-mode aerosol particles from the North Atlantic, J. Geophys. Res., 100, 23063-23074 1995.

Pósfai, M., Gelencsér, A., Simonics, R., Arató, K., Li, J., Hobbs, P. V., and Buseck, P. R.: Atmospheric tar balls: Particles from biomass and biofuel burning, J. Geophys. Res., 109(D6), D06213, doi:10.1029/2003JD004169, 2004.

Pósfai, M., Li, J., Anderson, J. R., and Buseck, P. R.: Aerosol bacteria over the Southern Ocean during ACE-1. Atmos. Res., 66, 231-240, 2003.

Pósfai, M., and Molnár, A.: Aerosol particles in the troposphere: A mineralogical introduction. In D.J. Vaughan, and W. R.A., Eds. Environmental Mineralogy, 2, 197-252, 2000.

Pósfai, M., Xu, H., Anderson, J. R., and Buseck, P. R.: Wet and dry sizes of atmospheric aerosol particles: A combined AFM-TEM study, Geophys. Res. Lett., 25, 1907-1910, 1998.

Radosevich, J., Wilson, W., Shinn, J., DeSantis, T., and Anderse, G.: Development of a high-volume aerosol collection system for the identification of air-borne micro-organisms, Lett. Appl. Microbiol., 34, 162-167, 2002.

Ramirez-Aguilar, K. A., Lehmpuhl, D. W., Michel, A. E., Birks, J. W., and Rowlen, K. L.: Atomic force microscopy for the analysis of environmental particles, Ultramicroscopy, 77, 187-194, 1999.

Ranjard, L., Poly, F., and Nazaret, S.: Monitoring complex bacterial communities using culture-independent molecular techniques: application to soil environment, Res. Microbiol., 151, 167-177, 2000.

Read, S.: Recovery efficiencies of nucleic acid extraction kits as measured by quantitative LightCycler ${ }^{T M}$ PCR, J. Clin. Pathol., 54, 86-90, 2001.

Russell, S. C., Czerwieniec, G., Lebrilla, C., Steele, P., Riot, V., Coffee, K., Frank, M., and Gard, E. E.: Achieving high detection sensitivity ( $14 \mathrm{zmol}$ ) of biomolecular ions in bioaerosol mass spectrometry, Anal. Chem., 77(15), 4734-4741, 2005.

Russell, S. C., Czerwieniec, G., Lebrilla, C., Tobias, H., Fergenson, D. P., Steele, P., Pitesky, M., Horn, J., Srivastava, A., Frank, M., and Gard, E. E.: Toward understanding the ionization of biomarkers from micrometer particles by bio-aerosol mass spectrometry, J. Am. Soc. Mass Spectr., 15(6), 900-909, 2004.

Rutledge, R.: Sigmoidal curve-fitting quantitative real-time PCR with the prospective of developing automated high-throughput applications, Nucl. Acid. Res., 32(22), e178, 2004.
Samburova, V., Didenko, T., Kunenkov, E., Emmenegger, C., Zenobi, R., and Kalberer, M.: Functional Group Analysis of High Molecular Weight Comounds in the Water-soluble Fraction of Organic Aerosols, Atmos. Environ., 41, 4703-4710, 2007.

Sannigrahi, P., Sullivan, A. P., Weber, R. J., and Ingall, E. D.: Characterization of water-soluble organic carbon in urban atmospheric aerosols using solid-state 13C NMR spectroscopy, Environ. Sci. Technol., 40, 666-672, 2006.

Sattler, B., Puxbaum, H., and Psenner, R.: Bacterial growth in supercooled cloud droplets, Geophys. Res. Lett., 28, 239-243, 2001.

Scheinert, P., Krausse, R., Ullmann, U., Söller, R., and Krupp, G.: Molecular differentiation of bacteria by PCR amplification of the 16 S-23 S rRNA spacer, J. Microbiol. Meth., 26, 103-117, 1996.

Schwieger, F. and Tebbe, C. C.: A new approach to utilize PCRsingle strand conformation polymorphism for $16 \mathrm{~S}$ rRNA genebased microbial community analysis, Appl. Environ. Microbiol., 64, 4870-4876, 1998.

Smalla, K., Oros-Sichler, M., Milling, A., Heuer, H., Baumgarte, S., Becker, R., Neuber, G., Kropf, S., Ulrich, A., and Tebbe, C. C.: Bacterial diversity of soils assessed by DGGE, T-RFLP and SSCP fingerprints of PCR-amplified 16S gene fragments: Do the different methods provide similar results?, J. Microbiol. Meth., 69, 470-479, 2007.

Sobanska, S., Coeur, C., Maenhaut, W., and Adams, F.: SEM-EDX Characterisation of Tropospheric Aerosols in the Negev Desert (Israel), J. Atmos. Chem., 44, 299-322, 2003.

Stetzenbach L. D., Buttner, M. P., and Cruz, P.: Detection and enumeration of airborne biocontaminants, Curr. Opin. Biotech., 15, 170-174, 2004.

Sullivan, R. C. and Prather, K. A.: Recent advances in our understanding of atmospheric chemistry and climate made possible by on-line aerosol analysis instrumentation, Anal. Chem., 77(12), 3861-3885, 2005.

Tobias, H. J., Schafer, M. P., Pitesky, M., Fergenson, D. P., Horn, J., Frank, M., and Gard, E. E.: Bioaerosol mass spectrometry for rapid detection of individual airborne Mycobacterium tuberculosis H37Ra particles, Appl. Environ. Microb., 71(10), 6086-6095, 2005.

Tong, Y. and Lighthart, B.: The annual bacterial particle concentration and size distribution in the ambient atmosphere in a rural area of the Willamette Valley, Oregon, Aerosol. Sci. Tech., 32, 393-403, 2000.

Vali, G.: Quantitative evaluation of experimental results on the heterogeneous freezing nucleation of supercooled liquids, J. Atmos. Sci., 28, 402-409, 1971.

van Borm, W. A., Adams, F. C., and Maenhaut, W.: Characterization of individual particles in the Antwerp aerosol, Atmos. Environ., 23(5), 1139-1151, 1989.

van Poppel, L. H., Friedrich, H., Spinsby, J., Chung, S. H., Seinfeld, J. H., and Buseck, P. R.: Electron tomography of nanoparticle clusters: Implications for atmospheric lifetimes and radiative forcing of soot, Geophys. Res. Lett., 32(24), 1-4, 2005.

van Wuijckhuijse, A. L., Stowers, M. A., Kleefsman, W. A., van Baar, B. L. M., Kientz, C. E., and Marijnissen, J. C. M.: Matrixassisted laser desorption/ionisation aerosol time-of-flight mass spectrometry for the analysis of bioaerosols: development of a fast detector for airborne biological pathogens, J. Aerosol Sci., 36(5-6), 677-687, 2005 
von Wintzingerode, F., Gobel, U. B., and Stackebrandt, E.: Determination of microbial diversity in environmental samples: pitfalls of PCR-based rRNA analysis, FEMS Microbiol. Rev., 21, 213-229, 1997.

Walter, J.: Size distribution characteristics of aerosols, in: Aerosol measurements: Principles, techniques, and applications, 2nd Edition, edited by: Baron, P. A, and Willeke, K., John Wiley and Sons, Inc., New York, NY, USA, 99-116, 2001.

Warren, G. J.: Identification and analysis of ina genes and proteins, in: Biological Ice Nucleation and its Applications, edited by: Lee Jr., R. E., Warren, G. J. and Gusta, L. V., APS Press, St. Paul, MN, USA, 85-100, 1995.

Warren, G., Corotto, L., and Wolber, P.: Conserved repeats in diverged ice nucleation structural genes from two species of Pseudomonas, Nucl. Acids Res., 14, 8047-8060, 1986.

Wilson, K. H., Wilson, W. J., Radosevich, J. L., Desantis, T. Z., Viswanathan, V. S., Kuczmarski, T. A., and Andersen, G. L.: High-density micro-array of small subunit ribosomal DNA probes, Appl. Environ. Microbiol., 68, 2535-2541, 2002.

Wise, M. E., Biskos, G., Martin, S. T., Russell, L. M., and Buseck, P. R.: Phase transitions of single salt particles studied using a transmission electron microscope with an environmental cell, Aerosol Sci. Tech., 39(9), 849-856, 2005.
Worobiec, A., de Hoog, J., Osan, J., Szaloki, I., Ro, C. U., and Van Grieken, R.: Thermal stability of beam sensitive atmospheric aerosol particles in electron probe microanalysis at liquid nitrogen temperature, Spectrochim. Acta B, 58(3), 479-496, 2003.

Yamamoto, S., Kasai, H., Arnold, D., Jackson, R., Vivian, A., and Harayama, S.: Phylogeny of the genus Pseudomonas: intrageneric structure reconstructed from the nucleotide sequences of $g y r B$ and $r p o D$ genes, Microbiology, 146, 2385-2394, 2000.

Zappoli, S., Andracchio, A., Fuzzi, S., Facchini, M. C., Gelencser, A., Kiss, G., Krivacsy, Z., Molnar, A., Meszaros, E., Hansson, H. C., Rosman, K., and Zebuhr, Y.: Inorganic, organic and macromolecular components of fine aerosol in different areas of Europe in relation to their water solubility, Atmos. Environ., 33, 27332743, 1999.

Zeng, Q.-Y., Westermark, S.-O., Rasmuson-Lestander, A.,, and Wang, X.-R.: Detection and quantification of Wallemia sebi in aerosols by real-time PCR, conventional PCR and cultivation, Appl. Environ. Microbiol., 70, 7295-7302, 2004. 